\title{
BUDDIES, LOVERS, AND DETOURS: AMERICA AND ITS ROAD MOVIES
}

T he American dream is a story about mobility. It is about leaving somewhere old for somewhere new and the many forks in the road along the way. Ever since Ford's Model T, this is a story about cars and nowhere is this more apparent, or louder, than in cinema. There are films with destinations and without, about journeys to visit or escape from family, about finding or losing oneself. Films about life and death on the open road. Films about America's past, present, and future. ${ }^{1}$ Reflecting on cinematic journeys, this article discusses the road movie genre from the perspective of 2021, and how contemporary road narratives intersect with race and gender. ${ }^{2}$ It does so by highlighting two American films-Queen o Slim (2019) and Unpregnant (2020)-and contextualizing them in the road movie genre at large.

Released one year apart, the posters for the two films preview a classic format: two people, one car. A single journey shared by two. Both films track drives across multiple states as a consequence of an accident. For Queen o Slim, the accident is a dead police

1. As the writer Michael Twitty points out, "the term 'United States' conveys politics but no dream" (2017: 7).

2. This article draws from my experience teaching "Head Out on the Highway: The Cultural History of the American Road Movie" at LMU Munich's Amerika-Institut (2019-2020). I am grateful to all of the students who contributed to making our discussions so rich, so lively, so thoughtful (and so fun), and to expanding my own perceptions of the genre. Also, many thanks to Rupali Naik for telling me about Unpregnant.
L. Sasha Cora

Center for the Humanities o-Social Change

Ca' Foscari

University of Venice Italy

(iD) 
officer and for Unpregnant it is an unplanned pregnancy. And both spotlight characters who hit rough patches of road that launch them on unexpected journeys. In discussing these films in tandem, it is not my intention to compare or measure the representation of life and death and race and privilege in one film against the other. Instead, my hope is that a discussion of these two road movies will yield an analysis of this genre's current temperature. How are these contemporary takes on the road movie a sign of their times?

ROUGH ROAD

With her hair pulled back, a woman in a red buttoned-up dress stands on top of a Ford Crown Victoria Police Interceptor that is submerged in a flooded street. The water nearly swallows its tires, coming up just below the blue letters that announce: New Orleans POLICE. In the background are rows of houses with water up to their doors. The car is still but the water around it ripples. A man's voice asks: "What happened after New Orleans?"-a scene that opens the music video for Beyoncé's "Formation" (2016). ${ }^{3}$ As Black studies scholar Omise'eke Tinsley describes, "images of water literally flood 'Formation"' (2018: 263). Images of racial injustice flood it too.

Directed by Melina Matsoukas, this rich visual collage jumps back and forth between choreographed and improvised dance scenes, joy rides and long braids hanging out of car windows, service at a Black church and a young boy-his hair hidden behind

CarCulture(s) Machines, Roads Mythologies a hoodie-dancing in front of a wall of riot police. ${ }^{4}$ As the song progresses, the police car sinks. ${ }^{5}$ By its end, Hurricane Katrina's

3. The voice is Messy Mya (Anthony Barre), a New Orleans rapper, who was shot while leaving his girlfriend's baby shower in 2010.

4. When he stops dancing the officers raise their hands in the sequence of a wave and the camera captures the writing on the wall. "Stop shooting us," spray paint demands. This references the 2012 shooting of seventeenyear-old Trayvon Martin and the hoodie as a symbol of racial profiling. See Tillis and Harris (2014).

5. The song and the music video were released as a surprise on February 6,2016 . The next day Beyoncé was one of the guests at Coldplay's Super Bowl 50 halftime show. Dressed in a black leather jacket-cum-bodysuit that recalled Michael Jackson's 1993 Super Bowl performance (and with her dancers dressed like Black Panthers), she performed "Formation" for the first time. This sparked heated debates, with some accusing her of spreading 
floodwaters have swallowed the car whole, first blanketing its roof and, finally, Beyoncé. The camera shifts from a side angle to an overhead view, exposing her face, eyes shut and mouth closed, as the water swallows everything.

Three years later, Matsoukas's feature directorial debut-Queen o Slim-returns to New Orleans. Released on November 27, 2019 by Universal Pictures, it features a screenplay by Lena Waithe and a story by Waithe together with James Frey. But before the protagonists make it to New Orleans, Queen (Jodie Turner-Smith) and Slim (Daniel Kaluuya) eat their way through an awkward Tinder date at a diner in Cleveland, Ohio. ${ }^{6}$ The scene is dark-both inside and out-and the lights glow a shade of green that matches Edward Hopper's iconic 1942 painting Nighthawks. Despite the atmospheric lighting, the date is going nowhere. Their chemistry is as cold as the snow that later falls outside.

Back in the car-a white Honda Accord with the license plate "TRUSTCOD"-their chemistry continues to freeze. Slim drives and Queen gives directions, his phone in her hands. He grabs his phone back, swerving the car. Blue lights flood the back window; a white police officer pulls them over. The atmosphere turns tense. Queen, a criminal defense attorney, questions the officer: does he have a warrant? While he searches the trunk, Slim asks him to "please hurry up," breathing on his hands to stay warm. "What did you say?" roars the officer as he draws his gun. "I'm reaching for my cell phone," Queen announces as she jumps out of the car. The officer shoots her in the thigh, blood splattering across her white jeans. Slim tackles him; the two scuffle and roll. He loses hold of his gun, it falls, Slim grabs it. One shot and the officer is dead.

Like Fyodor Dostoyevsky's 1866 Crime and Punishment, a six-part novel where one part chronicles the crime and five the punishment, Queen o Slim is one shot and mostly run. Eleven minutes into the two-hour and twelve-minute film is the shot that transforms

an anti-police message. Later, "Formation" won six MTV Video Music Awards and the Grammy for Best Music Video. Since then, it has become an anthem of sorts at demonstrations, including ones in support of the Black Lives Matter movement.

6. Their nicknames are never spoken out loud and their full names only revealed at the end: Angela Johnson and Ernest Hines. 
the protagonists into outlaws. Outlaws but not criminals, since Slim acted in self-defense. "Let's go," Queen orders. "We can't just leave him here," he protests. "Yes, we can," she confirms. The camera looks through the Honda's back window-the blue lights continue to flash. An overhead shot zooms out as they drive away, the body bloodying the snow. They argue about what to do, where to go. Queen's uncle (Bookeem Woodbine) lives in New Orleans and owes her a favor. It's still dark when they start the over one-thousandmile journey. Soulful R\&B fills the car-smooth music that cannot soothe.? Queen asks Slim to turn it down.

Instead of north to south, Unpregnant moves east to west. And instead of a romantic drama, it is one part 'female buddy' road film and one part teen comedy. An unplanned event, like in Queen a Slim, sparks its journey. Directed by Rachel Lee Goldenberg and released by HBO Max on September 10, 2020, the film begins in a high school bathroom. ${ }^{8}$ Seeking the privacy of a stall, seventeen-year-old Veronica Clarke (Haley Lu Richardson) waits for the result of her pregnancy test. Eyes closed, "you're fine," she coaches herself, only to open them to see the result is positive. Surprising her from above, Bailey Butler (Barbie Ferreira) peaks in, spotting the test. It is clear the two used to be close, but now they sit at different tables in the cafeteria: Veronica with the popular crowd and Bailey by herself. Disguising her panic, Veronica develops a plan. Athome, shewalks past the living room-where a drawing of the pope represents her parents' views on abortion-and up the stairs to her

CarCulture(s) Machines, Roads Mythologies bedroom, where she calls a clinic for "research for an assignment." She learns that she cannot make an appointment without parental consent because she is under eighteen. She asks about the closest clinic. After consulting Uber about a ride from Columbia, Missouri, to Albuquerque, New Mexico, over 900 miles (the estimated cost is $\$ 2,572.00)$, Veronica asks Bailey to drive her. ${ }^{9}$ She agrees. Veronica

7. Music is important in road movies, a lens this article unfortunately overlooks.

8. The film is an adaption of the young-adult novel of the same name by Jenni Hendricks and Ted Caplan.

9. Unpregnant was released in 2020 and that same year another film told a story of a young woman who had to travel from one state to another in order to access an abortion: Never Rarely Sometimes Always. In this film, 
is strict about the schedule; her parents think she is at a friend's house for the weekend studying and will be back Sunday night.

When they hit the road in a flashy blue Trans-Am with an eagle spreading its wings across the hood, Bailey, who is behind the wheel, cheers "Road trip!" Oueen o Slim, in contrast, is a road movie without the road trip, which is to say without the cheer. Knowing that the explanation of 'self-defense' holds little sway in a courtroom after a Black civilian's bullet has killed a white police officer, their decision to run is a reflection of structural racism and inequality in the United States. It is only later that Queen and Slim learn that, two years earlier, this police officer had killed an unarmed Black man.

Trust, and not having it, is a red thread in Unpregnant. Veronica does not trust her parents to respect her decision, she does not trust her friends to share what she is going through, nor does she trust her boyfriend. But she trusts Bailey. Bailey also anticipates that the road is not a place where trust is easily found, and has anticipated the need for self-defense. Veronica finds a taser in the car and asks Bailey why she has it. "Veronica, we're two teenage girls going across the country in the middle of the night," she matterof-factly responds. Later on, Veronica tells Bailey, "I'll get murdered if I travel alone," making it clear they have to stick together. Violence is a constant threat on the road. Cars expand the human body but they also harm it. The car can both be a means with which to escape, to run, but also a crime scene and a weapon.

\section{CAR TROUBLES}

A category of its own, the road movie overlaps with other genres-from westerns to thrillers-and charts stories of quests, discovery, or the coming-of-age. ${ }^{10}$ An open road represents a spectrum of possibilities; it also represents choices to make. But is an open road a democratic one? Not all forks in the road are safe and a driver's sense of safety is in tune with their race, class, gender, and sexuality.

the seventeen-year-old protagonist has a shorter journey; together with her cousin, she travels from Pennsylvania to New York City by bus.

10. Anne Hurault-Paupe points out that "genres are produced by the discourses which describe them" and reminds readers that when Bonnie and Clyde came out it was not considered a road movie (2014: 2). 
The road movie genre has many paths: from solo trips to buddies or couples and from families to strangers sharing a car. In the United States, these films also showcase an American representation of space. Employing dynamic montage sequences that show cars from the driver, the road, the passenger's, as well as a bird's eye point of view, these shots make the audience feel like they are along for the ride. But mobility is equally social as it is physical. Cultural studies scholar David Laderman identifies the genre's "fundamental core impulse" as the "rebellion against conservative social norms" (2002: 1). Most road movies, he argues, embrace the journey as a means of cultural critique and the genre's core "is constituted more precisely by a tension between rebellion and conformity" (20). Together these films ask: who feels safe on the road and who can make the road their own?

Despite their differences, what unites Queen o Slim and Unpregnant is that they destabilize the genre's traditional protagonist: a white man. Barbara Klinger, a film studies scholar, identifies how the American road movie genre is rooted in the entanglement between expansionism, imperialism, and race. Taking Easy Rider as the quintessential example, she writes how it "allows us to grasp how the road film, in particular its generically obligatory journey through landscapes and territories, participates within broader creative and cultural efforts to define the nation" (1997: 181). Cender also plays a role. The highway represents "a masculine space of freedom and escape" and the home "feminized domesticity"

CarCulture(s) Machines, Roads Mythologies (Schewe 2014: 39). Because of this binary distinction, queer theorist Elizabeth Schewe calls the car "a symbol of upward mobility and of masculine sexual potency" (41).

Taking an intersectional approach, Schewe draws from historian Cotton Seiler, who argues that "[t]hose who travel the public road without impediment are the implied citizens of what I call the 'republic of drivers'-a political imaginary of anonymity and autonomy that finds expression in the practices and landscapes of automobility" (1092). Paying attention to "a black highway consciousness" (1094) and prioritizing "Black road narratives" (1095), Seiler charts the car as both commodity and symbol. Historian Gretchen Sorin writes that during Jim Crow "the automobile held distinct importance and promise" and African Americans employed 
it as a weapon against segregation (2020: 9). Driving became a means with which to "claim the rights of citizenship and push the boundaries of racism" (48). As she explains: "For black people, mobility was always most highly prized because it was often and had historically been an impossibility" (11). Here, mobility refers to both geographical space as well as to socioeconomic status.

Because the car symbolizes "masculine autonomy" (Schewe 2014: 47) and driving can be interpreted "as an index of [...] participation in the 'American way of life'" (Seiler 2006: 1098), it matters who is driving, who is the passenger, and the dynamic between them. A classic road movie trope is a couple behind the wheel, usually one that clashes like oil and water at the film's beginning only to become inseparable by its end. Couples appear in two versions: romance and friendship (Laderman 2002: 7). Queen \& Slim exemplifies the former and Unpregnant the latter. The protagonists in both films take turns behind the wheel. They are both drivers and passengers, but one in each film drives more: Slim and Bailey.

One movie often drives in another film's lane, meaning the genre is self-referential. Queen o Slim is in dialogue with the outlaw couple model-for which Laderman credits Bonnie and Clyde (1967) with laying out the basic features-and Unpregnant follows the buddy quest model-blueprinted by Easy Rider (1969) (2002: 44). I later return to Bonnie and Clyde, but wish to first address another prototype from the American catalog: Thelma o Louise (1991). This film features a different type of outlaw: the accidental outlaw. Unpregnant's script even compares itself to Thelma \& Louise, but unlike it, does not blur the line between romance and friendship. As Lynda Hart, the late literary scholar, writes, "the semantic awkwardness that refers to the film as a 'female buddy' film points to the conceptual inability to think of the film in terms other than that of substitution" (1994: 436-437). She made this observation in 1994, which suggests that since then the label has shed some awkwardness. But in addition to representations of gender (a man and a woman on the road is a love story, but a man and a man or a woman and a woman is a story about friendship), Thelma o Louise hints at questions about sexuality that the film does 
not dare answer. Hart reads the bar scene as an "implication of erotic desire between them" (442).. Addressing its lesbian subtext, she argues: "As they go on the road, the film seems pressured to reinforce their sexual identities" (440). Hart continues: "For these romantic/sexual encounters allay any potential anxiety about the women's desire for men" (440). This leads to the question: "Could we imagine black women in these roles, or women whose physical appearances signified lesbian?"12 One can still ask this thirty years later. Bailey in Unpregnant comes out as queer, but the film never veers away from friendship territory.

HOPPING A RIDE

The third star of Thelma \& Louise is their turquoise 1966 Ford Thunderbird, a car they drive off a cliff in the film's iconic ending. ${ }^{13}$ Similarly, Queen \& Slim also ends with a fatal police encounter. However, unlike Thelma o Louise, their final ride is in the backseat of someone else's car. Neither one is behind the wheel.

Unpregnant also ends with the characters as passengers. And both films feature a cast of cars. Cars, as well as clothing, are visual symbols of character transformation and plot development. As already mentioned, a white Honda Accord opens Queen o Slim. Shortly thereafter, the two steal a white and red Ford pick-up truck. When they arrive in New Orleans, a just-missed run-in with the police changes their plans. Slim makes an "executive decision" that they should escape to Cuba, but first they have to make it

CarCulture(s) Machines, Roads Mythologies to Miami.14 They burn the truck and Uncle Earl gives them a Pontiac Catalina that is turquoise, a color echoing Thelma o Louise. But Slim is skeptical about the Pontiac's ability to disguise them for the more than eight-hundred-mile drive. "That's the whole

11. The bar scene ends with the accidental murder that transforms Thelma and Louise into outlaws.

12. Tongue-in-cheek, Smoke Signals (1998) features two women driving backwards: Velma and Lucy (see Gilroy 2001).

13. As Hart describes, "Their deaths are thus rendered as virtual but unrepresentable" (1994: 430).

14. A never-reached final destination is a trope in many films, like Badlands (Saskatchewan), Thelma o Louise (Mexico), and Boys Don't Cry (Memphis). As Holly in Badlands expresses: "Little by little we approached the border. A magical land beyond the reach of the law." 
point," Queen assures him-the car will hide them in plain sight. Kashema Hutchinson (2019), an education studies scholar, reads this scene through Erik Nielson's argument that Black Americans, specifically rappers, "use cars for (in)visibility to evade the police." Reading Wu-Tang Clan's song "Redbull" as an example, Nielson, a literary scholar who focuses on rap lyrics, writes: "Here and elsewhere, the car becomes another example of the tension between seeking attention and trying to avoid it: It is large, colorful [...] yet the driver and its occupants often remain unidentifiable" (1266). Returning to Queen \& Slim, Hutchinson (2019) summarizes how "the white gaze was temporarily blinded by the turquoise Catalina," allowing them to cross state lines.

Along the way, the Catalina breaks down. After it has been repaired, they ask the mechanic's son to take their picture, with the car in the frame. The last car they drive is a Mercedes Benz station wagon-Slim starts it with a screwdriver when they escape the house of Uncle Earl's friend, which a SWAT team raided the night before. The station wagon brings them to a Florida man (Bertrand E. Boyd II) with a mouth full of gold, who drives them in his Cadillac to the plane to Cuba. They have almost made it, but for the first time in the film they are both in the backseat. As soon as they get out of the car and walk toward the plane, a flock of police cars rattles up behind them. Queen and Slim hold hands. She says she'll never let go. Her last words are a question: "Can I be your legacy?" "You already are," he answers. A nervous officer, a woman, shoots her. After a six-day nationwide manhunt, six days on the road, Queen is dead. Slim picks her up, her body spread like a cross against his. The police open fire. The cross of bodies collapses to the ground. The Florida man-the last person they met-turned them in, a character Hutchinson describes as having "internalized the American ideology of individualism-everyone for themselves in their pursuit of justice, liberty and happiness." Like Thelma \& Louise, the movie ends with the protagonists' death. But unlike it, Queen and Slim did not choose death over being arrested by the police. They wanted to live but the last car they ride in is a black hearse.

In contrast, Veronica and Bailey's police run-in is not fatal. Somewhere in Texas, they stop to eat at a diner. Before they 
sit down, Veronica attracts the attention of a group of guys. Ignoring them, her and Bailey place their orders. Waiting for their food, they notice a cluster of cops investigating their car in the parking lot. Bailey stiffens, confessing that she didn't ask permission to take her "mom's asshole boyfriend's car." Veronica realizes the car is stolen. One of the guys who scrambled for her attention causes a distraction while the police search for the driver. "America, the beautiful," he sings. Veronica and Bailey make a quick exit, but are now without a car.

The rest of their journey is a burst of dramatic fragments. A ride from the diner leads to another potential ride, one offered by a female race car driver. Veronica catches on to Bailey's enthusiasm. "Yes, I like girls," she confirms. But then a friendly couple pushing a stroller offers them a ride all the way to Albuquerque. The next morning, when they wake up not where they planned to be, they realize the couple had overheard Bailey's phone call with the clinic and is trying to prevent the abortion. Veronica and Bailey escape, stealing the couple's GMC Yukon, but are chased down by a "pregnancy clinic bus" only to reach a cliff. "Let's keep going," Bailey says. "What?" Veronica reacts. "I'm kidding. I'm not doing a Thelma and Louise. I'm not driving off a cliff," Bailey replies. They jump out of the SUV and, once again, are on foot. After a failed attempt to hop a train, Veronica yells at the world, cursing the fact that she has to drive 996 miles through three

CarCulture(s) Machines, Roads Mythologies states only to become stranded because of her own's prohibitive laws. "Fuck you Missouri State Legislature," she howls. But then, at the closest bus stop, they notice a dusty sign for a limo service and pay its driver to take them the rest of the way. At this point, similar to both Thelma o Louise and Queen o Slim, Veronica's appearance has changed. A black band T-shirt replaces her soft cream and pastel long-sleeve. A baseball cap hides her blond hair.

Just as cars change throughout the journeys, clothes do too. And, like cars, clothing can hide or reveal. At Uncle Earl's, Queen and Slim raid the closets. He changes into a Bordeaux velour tracksuit, she into a tiger print mini dress with snakeskin boots. Their hair also changes: Slim has a shaved head and, without 
her waist-length braids, Queen's hair is tapered, short, natural. ${ }^{15}$ Queen and Slim live the rest of the journey in these clothes. They die in them too.

When Slim asks the mechanic's son to take their picture, Queen disapproves. "C'mon," he coaxes, "I want proof that we were here." Around this point, aided by the previous night when they risked their cover to go dancing, their dynamic begins to change. Their disagreements become flirtatious. ${ }^{16}$ Back in the diner, the moment they met, when Slim asked Queen why she picked him, she replied that she liked his picture. "You have this sad look on your face," she confessed, "I felt sorry for you." He confesses his dad took his picture, that he does not need a lot of pictures because he knows what he looks like. "Pictures aren't just about vanity," she disagrees. "They're proof of your existence."

Veronica agrees. Throughout their trip, she posts pictures on social media. The first one frames the night sky with the caption "selfcare." Bailey asks why she is posting at all, to which she answers to keep up appearances, to wade off suspicion that her weekend is anything other than ordinary. This points to photography as a form of surveillance. For Veronica, posting images online is act of self-surveillance. She posts one thing, but lives another. The time on the road allows her to shed the social conventions of her everyday life. It grants her perspective and, typical of the genre, a new sense of self.

For Queen and Slim, video functions as a witness. They learn that the bodycam footage of the shooting has gone viral. The video is a witness to racialized oppression that raises questions regarding accountability. A review describes Queen o Slim as a "meditation on race relations and police brutality," for which Matsoukas drew inspiration from films like Spike Lee's Do the Right Thing (1989)

15. For the importance of hair in the film see Allen (2019).

16. The day after the mechanic repairs the car, his city holds a demonstration in Queen and Slim's support. At the frontline his son Junior impulsively shoots a police officer (which the camera shows) and, in turn, is killed (which is mentioned but not shown). The protest scene alternates back and forth with a sex scene in the car that represents the bond Queen and Slim have forged from being together on the road. Also representing this shift, the film employs two voiceovers. For more about how voiceovers add texture to a film's narrative see McGettigan (2001). 
and the Mexican road movie Y Tu Mamá También (2001), but, above all, "YouTube videos of black people being pulled over by the police or encountering law enforcement and it not necessarily ending well" (Kelley 2019).

When Queen and Slim arrive in New Orleans, Uncle Earl has already seen the video. His first words of welcome are: "Well, if it isn't the Black Bonnie and Clyde." "I don't know what the news is saying," Queen retorts, "but whatever it is it's not true." The story's plot attracted Matsoukas to make this her first feature film. "It was provocative, it was political, it was an opportunity, I felt, to move the culture forward" (Kelley 2019). But she disagrees with describing the film as a Black Bonnie and Clyde:

I think it's a really simplistic and diminishing way to talk about our film [...] I don't really agree with basing black films on any white archetype. [...] there's a huge difference in who Queen and Slim are. They're not criminals on the run, they're two very human people who have a shared experience that was not their choice. (Kelley 2019)

Matsoukas underlines that Queen and Slim are not criminals. Instead, they are accidental outlaws. They have to run because the law will not protect them.

Beyond Arthur Penn's 1967 title, lan Leong, Mike Sell, and Kelly Thomas have defined a road movie subgenre: the Bonnie-andClyde film (1997: 72). 17 They argue that "the Bonnie-and-Clyde

CarCulture(s) Machines, Roads Mythologies genre purposely fragments certain narrative conventions of classic Hollywood cinema but at the same time shares certain assumptions with popular notions of conservatism, namely that love is good and affluence is right" (71). Moreover, this genre "maps the intersection of capitalism and desire" (85). Oueen o Slim maps neither. It is an accidental love story. As one review points out: "They flee rather than reporting the shooting as self-defense because they believe they have no other choice. [...] Whites are

17. Bonnie and Clyde opens with an unprecedented sexualized scene and closes with an unprecedented violent scene, representing the end of the Hayes code. It was one of the first features to extensively use squibs-explosive charges filled with stage blood-making it one of the first mainstream American films to depict graphic violence. See Peebles (2004). 
innocent until proven guilty: Blacks are guilty until proven innocent" (Sharp 2020: 298).

In her 2020 book Driving While Black, Sorin identifies the tension between the car's association with freedom and the restraints that govern driving through "a web of regulatory practices" that spans tests and licenses, speed limits and police stops (141-142). The contrast between an open road and its many rules. She discusses how driving continues to be "a potentially dangerous activity, especially when it comes to police traffic stops" for African Americans (19). The deaths of George Floyd and Daunte Wright, and so many others, tragically represent this. Queen o Slim contributes a fictionalized example to the urgent need for systemic change, just as the writing on the wall in Beyoncé's "Formation" insists. Referring to the likes of traffic stops, Sorin writes: "We should see these dismal events not simply as a legacy of slavery and racism but also as the continuation of restrictions on mobility that have been placed on African Americans from the start" (2020: 19). Although the American dream is about mobility, not all Americans have, or have had, the access to this right.

\section{CONCLUSION}

The ending of Queen o Slim is tragic. They never make it back home. Veronica and Bailey do (but only after calling their mothers who buy them plane tickets) and have rekindled their friendship along the way. As a genre, road movies depict detours, run-ins and near run-ins with the law, the symbolic and cultural capital of cars, the roadside diner as a liminal and, sometimes, democratic space, and the kindness and wrath of strangers. Driving is a blur of contradictions. It is a practice that both isolates and connects. It brings some people together and keeps others apart. "Cars are terrifying," author Adam Copnik writes, "and cars are normality itself" (2015).

Sorin makes the crucial distinction that Driving While Black is not simply a story about African Americans. Instead, she uses that lens to tell a history that "broadens and deepens our understanding of the automobile's role in American life and history and encourages us to consider the context within which today's race relations developed" (2020: 21). I argue the same about Queen \& Slim 
and Unpregnant. Taken together, these films not only narrate the fictionalized stories of a racist encounter with a police officer that transforms two young African Americans into accidental outlaws-and then kills them-or how prohibitive regulations force a young woman to drive across three states to exercise her right to make her own decisions about her body. These films represent contemporary American life and the restraints some citizens continue to battle in efforts to feel at home on the road, to feel at home in America.

A film is able to take a culture's temperature, to portray a society at a particular moment. A film will never be completely representative, but it will offer a view on current debates, attitudes, and ongoing tensions. Both Queen o Slim and Unpregnant represent a period in American politics that has continued to shift to the right, as exemplified by, first, Donald Trump's presidency and, second, policies passed by state governments, such as Texas, to just about ban abortions. Together these two films represent a period in which the safety of Black Americans and the rights of women have continued to becompromised, but not unchallenged. 
Allen, Maya. "Oueen o Slim's Costume Designer and Hairstylist on the Film's Powerful Imagery." Marie Claire, 13 December 2019, https://www.marieclaire.com/beauty/a30188862/ queen-and-slim-shiona-turnini-brian-badie-interview/. Accessed 1 Dec. 2021.

Badlands. Terrence Malick, Warner Bros., 1973.

Bonnie and Clyde. Arthur Penn, Warner Bros., 1967.

Boys Don't Cry. Kimberly Peirce, Fox Searchlight Pictures, 1999.

Easy Rider. Dennis Hopper, Columbia Pictures, 1969.

"Formation." YouTube, uploaded by Beyoncé, 9 December 2016, https://www. youtube.com/watch?v=WDZJPJV__bQ. Accessed 1Dec. 2021.

Dostoyevsky, Fyodor. Crime and Punishment. Translated by Constance Garnett, Dover Publications, 2001.

Do the Right Thing. Spike Lee, Universal Pictures, 1989.

Gilroy, Jhon Warren. "Another Fine Example of the Oral Tradition? Identification and Subversion in Sherman Alexie's Smoke Signals." Studies in American Indian Literatures, vol. 13, no. 1, 2001, pp. 23-42.

Gopnik, Adam. "The Driver's Seat." New Yorker, 26 January 2015, https:// www.newyorker.com/magazine/2015/02/02/drivers-seat. Accessed 1 Dec. 2021.

Hart, Lynda. “'Til Death Do Us Part: Impossible Spaces in Thelma and Louise." Journal of the History of Sexuality vol. 4, no. 3, 1994, pp. 430-446.

Hurault-Paupe, Anne. "The Paradoxes of Cinematic Movement: Is the Road Movie a Static Genre?" Miranda vol. 10, 2014, pp. 1-15.

Hutchinson, Kashema. "Queen \& Slim: The Rides." Kashema, 10 December 2019, https://kashema.com/2019/12/10/queenslim-the-rides/. Accessed 1 Dec. 2021.

Kelley, Sonayia. "Lena Waithe and Melina Matsoukas don't want you comparing 'Queen \& Slim' to 'Bonnie and Clyde.'” LA Times, 30 October 2019, https://www.latimes.com/entertainment-arts/ 
movies/story/2019-10-30/queen-and-slim-melina-matsoukas-lena-waithe. Accessed 1 Dec. 2021.

Klinger, Barbara. "The Road to Dystopia: Landscaping the Nation in Easy Rider." The Road Movie Book, edited by Steven Cohan and Ina Rae Hark. Routledge, 1997, pp. 179-203.

Laderman, David. Driving Visions: Exploring the Road Movie. University of Texas Press, 2002.

Leong, Ian, Mike Sell, and Kelly Thomas. "Mad Love, Mobile Homes, and Dysfunctional Dicks." The Road Movie Book, edited by Steven Cohan and Ina Rae Hark. Routledge, 1997, pp. 70-89.

Never Rarely Sometimes Always. Eliza Hittman, Focus Features, 2020.

Nielson, Erik. “'Can't C Me': Surveillance and Rap Music." Journal of Black Studies vol. 40, 2010, pp. 1254-1274.

McGettigan, Joan. “Interpreting a Man's World: Female Voices in Badlands and Days of Heaven." Journal of Film and Video vol. 52, no. 4, 2001, pp. 33-43.

Peebles, Stacey. "Gunning for a New Slow Motion: The 45-Degree Shutter and the Representation of Violence." Journal of Film and Video, vol. 56, no. 2, 2004, pp. 45-54.

Queen \& Slim. Melina Matsoukas, Universal Pictures, 2019.

Sharp, William. "Film Review: Matsoukas, M. (Director/Producer), Waithe, L. (Screenplay/Producer), \& Frey, J. (Story by). Queen a Slim [Motion Picture]. Universal Pictures, 2019. Running

CarCulture(s) Machines, Roads Mythologies Time, 2 hours and 12 minutes." Journal of African American Studies, vol. 42, 2020, pp. 297-301.

Schewe, Elizabeth. "Highway and Home: Mapping Feminist-Transgender Coalition in Boys Don't Cry." Feminist Studies vol. 40, no. 1, 2014, pp. 39-64.

Seiler, Cotten. "'So That We as a Race Might Have Something Authentic to Travel By': African American Automobility and Cold-War Liberalism." American Quarterly vol. 58, no. 4, 2006, pp. 1091-1117.

Smoke Signals. Chris Eyre, Miramax, 1998.

Sorin, Gretchen. Driving While Black: African American Travel and the Road to Civil Rights. Liveright, 2020.

Thelma o Louise. Ridley Scott, Metro-Goldwyn-Mayer, 1991. 
Tillis, Antonio D., and Emmanuel Harris, editors. The Trayvon Martin in US: An American Tragedy. Peter Lang, 2014.

Tinsley, Omise'eke. Beyoncé in Formation: Remixing Black Feminism. University of Texas Press, 2018.

Twitty, Michael. The Cooking Cene: A Journey Through African American Culinary History in the Old South. Amistad, 2017.

Unpregnant. Rachel Lee Goldenberg, HBO Max, 2020.

Y Tu Mamá También. Alfonso Cuarón, 20th Century Fox, 2001.

L. Sasha Cora Center for the Humanities o-Social Change Ca' Foscari University of Venice Italy 
